\title{
Leeuwenhoekiella palythoae sp. nov., a new member of the family Flavobacteriaceae
}

\author{
Olga I. Nedashkovskaya, ${ }^{1}$ Marc Vancanneyt, ${ }^{2}$ Seung Bum Kim, ${ }^{3}$ \\ Natalia V. Zhukova, ${ }^{4}$ Ji Hye $\mathrm{Han}^{3}$ and Valery V. Mikhailov ${ }^{1}$ \\ ${ }^{1}$ Pacific Institute of Bioorganic Chemistry of the Far-Eastern Branch of the Russian Academy of \\ Sciences, Pr. 100 Let Vladivostoku 159, 690022 Vladivostok, Russia \\ ${ }^{2}$ BCCM/LMG Bacteria Collection, and Laboratory of Microbiology, Ghent University, \\ Ledeganckstraat 35, B-9000 Ghent, Belgium \\ ${ }^{3}$ Department of Microbiology, School of Bioscience and Biotechnology, Chungnam National \\ University, 220 Gung-dong, Yuseong, Daejeon 305-764, Republic of Korea \\ ${ }^{4}$ Institute of Marine Biology of the Far-Eastern Branch of the Russian Academy of Sciences, \\ Pal'chevskogo St. 17, 690032, Vladivostok, Russia
}

Correspondence

Olga I. Nedashkovskaya olganedashkovska@yahoo.com

\begin{abstract}
The taxonomic status of a novel, heterotrophic, strictly aerobic, gliding and yellow-orangepigmented bacterium (strain KMM 6264 ${ }^{\mathrm{T}}$ ), associated with the coral Palythoa, was determined. The 16S rRNA gene sequence analysis indicated that strain KMM $6264^{\top}$ clustered with the recognized species of the genus Leeuwenhoekiella of the family Flavobacteriaceae with 96.498.2\% sequence similarity. DNA-DNA reassociation levels between the isolate and the type strains of Leeuwenhoekiella species were 15-22\%. The DNA G+C content was 41.2 mol\%. The phylogenetic evidence and the results of genomic and phenotypic analyses showed that the isolate should be classified as a member of a novel species of the genus Leeuwenhoekiella, for which the name Leeuwenhoekiella palythoae sp. nov. is proposed. The type strain is $\mathrm{KMM} 6264^{\top}$ $\left(=\right.$ KCTC $22020^{\top}=$ LMG $\left.24856^{\top}\right)$.
\end{abstract}

The genus Leeuwenhoekiella was created to accommodate heterotrophic, strictly aerobic, yellow-pigmented and gliding marine bacteria (Nedashkovskaya et al., 2005). It belongs to the family Flavobacteriaceae (phylum Bacteroidetes) (Bernardet et al., 2002) and comprises three recognized species, Leeuwenhoekiella aequorea, Leeuwenhoekiella marinoflava (formerly Cytophaga marinoflava) and Leeuwenhoekiella blandensis (Reichenbach, 1989; Nedashkovskaya et al., 2005; Pinhassi et al., 2006). It should be noted that five strains of $L$. aequorea were isolated from an Antarctic seawater sample and one strain was recovered from a common inhabitant of the East Sea, the sea urchin Strongylocentrotus intermedius.

Strain KMM $6264^{\mathrm{T}}$ was isolated from a coral of the genus Palythoa, which had been collected from Vanfong Bay, South China Sea, Vietnam. For strain isolation, $0.1 \mathrm{ml}$ tissue homogenate was transferred onto medium containing $\left(1^{-1}\right)$ : $5.0 \mathrm{~g}$ Bacto peptone (Difco), $5.0 \mathrm{~g}$ sucrose, $1.0 \mathrm{~g}$ glucose, $2.5 \mathrm{~g}$ yeast extract (Difco), $0.1 \mathrm{~g} \mathrm{KH}_{2} \mathrm{PO}_{4}, 0.1 \mathrm{~g}$ $\mathrm{MgSO}_{4}$ and $15.0 \mathrm{~g}$ Bacto agar (Difco), using $30 \%(\mathrm{v} / \mathrm{v})$ natural seawater and $70 \%(\mathrm{v} / \mathrm{v})$ distilled water. After primary isolation and purification, the strain was cultivated

The GenBank/EMBL/DDBJ accession number for the 16S rRNA gene sequence of strain KMM $6264^{\top}$ is FJ405187. at $28{ }^{\circ} \mathrm{C}$ on the same medium or on marine agar 2216 (MA) and stored at $-80{ }^{\circ} \mathrm{C}$ in marine broth 2216 (both from Difco) supplemented with $20 \%$ (v/v) glycerol.

An almost-complete 16S rRNA gene sequence (1480 nucleotides) of strain KMM $6264^{\mathrm{T}}$ was determined by following the procedure described previously (Vancanneyt et al., 2004). The sequence data were aligned with those of representative members of the family Flavobacteriaceae, retrieved from GenBank, and the construction of a neighbour-joining (Saitou \& Nei, 1987) phylogenetic tree and a bootstrap analysis were carried out as described by Cho et al. (2006). The maximum-likelihood (Felsenstein, 1993) and maximum-parsimony (Kluge \& Farris, 1969) algorithms gave similar results (data not shown).

The phylogenetic analysis indicated that strain KMM $6264^{\mathrm{T}}$ forms a distinct lineage within the genus Leeuwenhoekiella (Fig. 1). The 16S rRNA gene sequence similarities between the coral isolate and Leeuwenhoekiella species with validly published names ranged from 96.4 to $98.2 \%$. L. blandensis MED $217^{\mathrm{T}}$, which had been isolated from a seawater sample collected from the Mediterranean Sea, was the closest relative of strain KMM $6264^{\mathrm{T}}$, with a sequence similarity of $98.2 \%$. Based on the results of this analysis and according to the recommendation of Stackebrandt \& 


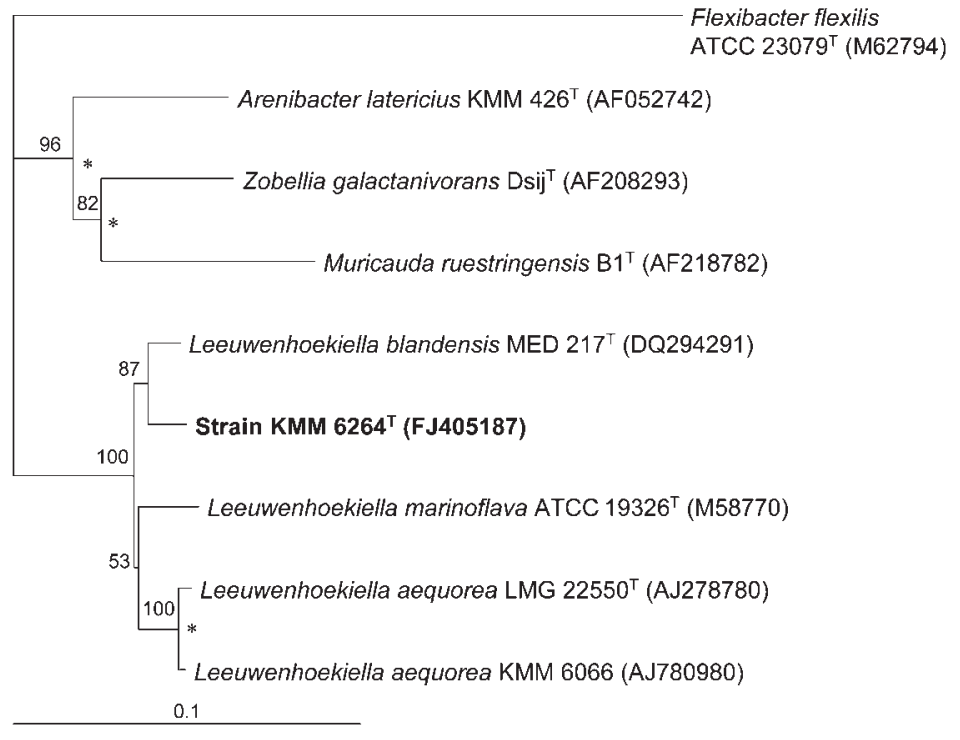

Fig. 1. Phylogenetic tree of Leeuwenhoekiella species and related taxa based on 16S rRNA gene sequences. Percentages at nodes are levels of bootstrap support based on 1000 resamplings. Asterisks indicate branches that were also recovered in maximum-likelihood and maximum-parsimony trees. The sequence of Flexibacter flexilis ATCC $23079^{\top}$ was used as an outgroup. Bar, 0.1 substitutions per nucleotide position.
Ebers (2006), strain KMM $6264^{\mathrm{T}}$ may be considered as a member of a novel species of the genus Leeuwenhoekiella.

Genomic DNA was isolated following the method of Marmur (1961) and the $\mathrm{G}+\mathrm{C}$ content was determined by using the thermal denaturation method (Marmur \& Doty, 1962). The DNA G + C content of strain KMM $6264^{\mathrm{T}}$ was $41.2 \mathrm{~mol} \%$.

DNA-DNA hybridization was performed spectrophotometrically and initial renaturation rates were determined as described by De Ley et al. (1970). The DNA-DNA reassociation values between strain KMM $6264^{\mathrm{T}}$ and the type strains of the recognized Leeuwenhoekiella species varied from 15 to $22 \%$. These data clearly indicated that the isolate constitutes a novel species within the genus Leeuwenhoekiella (Wayne et al., 1987).

For determination of whole-cell fatty acid profiles, strain KMM $6264^{\mathrm{T}}$ was grown at $28{ }^{\circ} \mathrm{C}$ for $48 \mathrm{~h}$ on MA. Fatty acid methyl esters were extracted and analysed as described previously (Nedashkovskaya et al., 2006). The cellular fatty acids of strain KMM $6264^{\mathrm{T}}$ that accounted for more than $1 \%$ of the total fatty acids were iso- $\mathrm{C}_{15: 1}(25.2 \%)$, iso$\mathrm{C}_{15: 0} 3-\mathrm{OH}(21.6 \%)$, iso- $\mathrm{C}_{15: 0}(18.6 \%)$, iso- $\mathrm{C}_{17: 1}(9.8 \%)$, iso- $\mathrm{C}_{17: 0} 3-\mathrm{OH}(6.9 \%), \mathrm{C}_{15: 0}(2.9 \%), \mathrm{C}_{16: 0}(2.4 \%)$, $\mathrm{C}_{16: 1} \omega 7 c(1.8 \%)$, iso- $\mathrm{C}_{16: 0}(1.2 \%)$ and $\mathrm{C}_{14: 0} 3-\mathrm{OH}$ $(1.0 \%)$.

Phenotypic analysis of strain KMM $6264^{\mathrm{T}}$ was performed using previously described methods (Nedashkovskaya et al., 2003, 2004). API 20NE and API ZYM galleries (bioMérieux) were also used according to the manufacturer's instructions except that the galleries were incubated at $28{ }^{\circ} \mathrm{C}$. The physiological, biochemical and morphological characteristics of strain KMM $6264^{\mathrm{T}}$ are listed in the species description and in Table 1. Strain KMM $6264^{\mathrm{T}}$ shared many features with the recognized Leeuwenhoekiella species. Cells are motile by gliding, produce alkaline phosphatase, catalase, oxidase and $\beta$-galactosidase, utilize L-arabinose, D-glucose, lactose, D-mannose and sucrose, hydrolyse gelatin, starch and Tweens 40 and 80 and do not require $\mathrm{NaCl}$ for growth. However, the isolate differed from Leeuwenhoekiella species by the presence of acid production from L-arabinose, cellobiose, lactose, maltose and L-rhamnose, by its inability to hydrolyse casein and Tween 20 and by its susceptibility to gentamicin, kanamycin, neomycin and polymyxin. Strain KMM $6264^{\mathrm{T}}$ could be differentiated from each of the recognized species of the genus Leeuwenhoekiella by means of a set of phenotypic properties (Table 1).

On the basis of the data presented above, we propose a novel species, Leeuwenhoekiella palythoae sp. nov.

\section{Description of Leeuwenhoekiella palythoae sp. nov.}

Leeuwenhoekiella palythoae (pa.ly.tho'a.e. N.L. gen. n. palythoae of Palythoa, the genus of coral from which the type strain was isolated).

Cells are Gram-negative rods, motile by gliding, $0.4-0.5 \mu \mathrm{m}$ in width and 1.4-3.2 $\mu \mathrm{m}$ in length. On MA, colonies are 2$3 \mathrm{~mm}$ in diameter, circular with entire edges and yelloworange in colour. Optimal growth is observed with 3-4\% $\mathrm{NaCl}$. Decomposes aesculin. Does not hydrolyse agar. Forms acid from trehalose, but not from L-sorbose, $\mathrm{N}$ acetylglucosamine, citrate, adonitol, dulcitol or inositol. Does not utilize inositol, sorbitol, malonate or citrate. According to API ZYM, esterase lipase (C8), leucine and valine arylamidase, trypsin, acid phosphatase, naphtholAS-BI-phosphohydrolase, $\alpha$-galactosidase, $\alpha$ - and $\beta$-glucosidase, $N$-acetylglucosaminidase and $\alpha$-mannosidase activities are present, but esterase (C4), lipase (C14), cystine arylamidase, $\alpha$-chymotrypsin, $\beta$-glucuronidase and $\alpha$ fucosidase activities are not present. Other biochemical 
Table 1. Differential phenotypic characteristics of Leeuwenhoekiella species

Taxa: 1, KMM $6264^{\mathrm{T}}$ (Leeuwenhoekiella palythoae sp. nov.); 2, L. aequorea $(n=5) ; 3$, L. blandensis $(n=1) ; 4$, L. marinoflava ( $\left.n=1\right)$. Data were taken from Pinhassi et al. (2006), Nedashkovskaya et al. (2005) and this study. All taxa were positive for the following: gliding motility; alkaline phosphatase, catalase, oxidase and $\beta$-galactosidase activities; utilization of L-arabinose, D-glucose, lactose, D-mannose and sucrose; hydrolysis of gelatin, starch and Tweens 40 and 80; acid production from glycerol; and susceptibility to carbenicillin, chloramphenicol, doxycycline and erythromycin. All taxa were negative for the following: nitrate reduction; production of flexirubin-type pigments; hydrolysis of DNA, urea, cellulose and chitin; acid production from melibiose, raffinose and $\mathrm{N}$-acetylglucosamine; and $\mathrm{H}_{2} \mathrm{~S}$ and indole production. +, Positive; - , negative; $\mathrm{V}$, variable; $n$, number of strains.

\begin{tabular}{|c|c|c|c|c|}
\hline Characteristic & 1 & 2 & 3 & 4 \\
\hline \multicolumn{5}{|l|}{ Growth conditions } \\
\hline Salinity range $(\%)$ & $0-12$ & $0-15$ & $0-17$ & $0-15$ \\
\hline Temperature range $\left({ }^{\circ} \mathrm{C}\right)$ & $4-38$ & $4-37$ & $10-41$ & $4-37$ \\
\hline Temperature optimum $\left({ }^{\circ} \mathrm{C}\right)$ & $23-25$ & $23-25$ & $28-30$ & $21-23$ \\
\hline \multicolumn{5}{|l|}{ Acid formation from: } \\
\hline L-Arabinose, cellobiose, lactose, maltose, L-rhamnose & + & - & - & - \\
\hline D-Galactose & + & + & - & + \\
\hline D-Glucose & + & - & + & - \\
\hline Sucrose & + & + & - & - \\
\hline DL-Xylose & - & - & + & - \\
\hline Mannitol & - & + & - & - \\
\hline Utilization of mannitol & - & + & - & - \\
\hline Hydrolysis of casein, Tween 20 & - & + & + & + \\
\hline \multicolumn{5}{|l|}{ Susceptibility to: } \\
\hline Ampicillin, oleandomycin, streptomycin & + & $\mathrm{V}$ & - & - \\
\hline Benzylpenicillin & + & $\mathrm{V}$ & - & + \\
\hline Gentamicin, kanamycin, neomycin, polymyxin & + & - & - & - \\
\hline Lincomycin & - & + & + & + \\
\hline Tetracycline & + & + & + & - \\
\hline DNA G $+\mathrm{C}$ content $(\mathrm{mol} \%)$ & 41.2 & $35-36$ & 42.5 & 38 \\
\hline
\end{tabular}

and physiological characteristics are listed in Table 1. Predominant fatty acids $(>5 \%)$ are iso- $\mathrm{C}_{15: 1}$, iso- $\mathrm{C}_{15: 0} 3-$ $\mathrm{OH}$, iso- $\mathrm{C}_{15: 0}$, iso- $\mathrm{C}_{17: 1}$ and iso- $\mathrm{C}_{17: 0} 3-\mathrm{OH}$. The DNA $\mathrm{G}+\mathrm{C}$ content of the type strain is $41.2 \mathrm{~mol} \%$.

The type strain, KMM $6264^{\mathrm{T}}$ (=KCTC $22020^{\mathrm{T}}=\mathrm{LMG}$ $24856^{\mathrm{T}}$ ), was isolated from the coral Palythoa, collected from Vanfong Bay, South China Sea, Vietnam.

\section{Acknowledgements}

This research was supported by grants from the Russian Foundation for Basic Research (no. 08-04-00099), the State Contract 02.518.11.7169 from the Federal Agency for Science and Innovations of the Russian Federation and Presidium of the Russian Academy of Sciences 'Molecular and Cell Biology'.

\section{References}

Bernardet, J.-F., Nakagawa, Y. \& Holmes, B. (2002). Proposed minimal standards for describing new taxa of the family Flavobacteriaceae and emended description of the family. Int J Syst Evol Microbiol 52, 1049-1070.

Cho, S. H., Han, J. H., Seong, C. N. \& Kim, S. B. (2006). Phylogenetic diversity of acidophilic sporoactinobacteria isolated from various soils. J Microbiol 44, 600-606.
De Ley, J., Cattoir, H. \& Reynaerts, A. (1970). The quantitative measurement of DNA hybridization from renaturation rates. Eur $J$ Biochem 12, 133-142.

Felsenstein, J. (1993). PHYLIP (phylogeny inference package) version 3.5.1. Distributed by the author. Department of Genome Sciences, University of Washington, Seattle, USA.

Kluge, A. G. \& Farris, F. S. (1969). Quantitative phyletics and the evolution of anurans. Syst Zool 18, 1-32.

Marmur, J. (1961). A procedure for the isolation of deoxyribonucleic acid from microorganisms. J Mol Biol 3, 208-218.

Marmur, J. \& Doty, P. (1962). Determination of the base composition of deoxyribonucleic acid from its thermal denaturation temperature. $J$ Mol Biol 5, 109-118.

Nedashkovskaya, O. I., Kim, S. B., Han, S. K., Lysenko, A. M., Rohde, M., Zhukova, N. V., Falsen, E., Frolova, G. M., Mikhailov, V. V. \& Bae, K. S. (2003). Mesonia algae gen. nov., sp. nov., a novel marine bacterium of the family Flavobacteriaceae isolated from the green alga Acrosiphonia sonderi (Kütz) Kornm. Int J Syst Evol Microbiol 53, 1967-1971.

Nedashkovskaya, O. I., Kim, S. B., Han, S. K., Rhee, M. S., Lysenko, A. M., Falsen, E., Frolova, G. M., Mikhailov, V. V. \& Bae, K. S. (2004). Ulvibacter litoralis gen. nov., sp. nov., a novel member of the family Flavobacteriaceae isolated from the green alga Ulva fenestrata. Int $J$ Syst Evol Microbiol 54, 119-123.

Nedashkovskaya, O. I., Vancanneyt, M., Dawyndt, P., Engelbeen, K., Vandemeulebroecke, K., Cleenwerck, I., Hoste, B., Mergaert, J., Tan, T.-L. \& other authors (2005). Reclassification of [Cytophaga] 
marinoflava Reichenbach 1989 as Leeuwenhoekiella marinoflava gen. nov., comb. nov. and description of Leeuwenhoekiella aequorea sp. nov. Int J Syst Evol Microbiol 55, 1033-1038.

Nedashkovskaya, O. I., Kim, S. B., Zhukova, N. V., Kwak, J., Mikhailov, V. V. \& Bae, K. S. (2006). Mesonia mobilis sp. nov., isolated from seawater, and emended description of the genus Mesonia. Int J Syst Evol Microbiol 56, 2433-2436.

Pinhassi, J., Bowman, J. P., Nedashkovskaya, O. I., Lekunberri, I., Gomez-Consarnau, L. \& Pedrós-Alió, C. (2006). Leeuwenhoekiella blandensis sp. nov., a genome-sequenced marine member of the family Flavobacteriaceae. Int J Syst Evol Microbiol 56, 14891493.

Reichenbach, H. (1989). The order Cytophagales Leadbetter 1974, $99^{\mathrm{AL}}$. In Bergey's Manual of Systematic Bacteriology, vol. 3, pp. 20112073. Edited by J. T. Staley, M. P. Bryant, N. Pfennig \& J. C. Holt. Baltimore: Williams \& Wilkins.
Saitou, N. \& Nei, M. (1987). The neighbor-joining method: a new method for reconstructing phylogenetic trees. Mol Biol Evol 4, 406425.

Stackebrandt, E. \& Ebers, J. (2006). Taxonomic parameters revisited: tarnished gold standards. Microbiol Today 33, 152-155.

Vancanneyt, M., Mengaud, J., Cleenwerck, I., Hoste, B., Dawyndt, P., Degivry, M. C., Ringuet, D., Janssens, D. \& Swings, J. (2004). Reclassification of Lactobacillus kefirgranum Takizawa et al. 1994 as Lactobacillus kefiranofaciens subsp. kefirgranum subsp. nov. and emended description of $L$. kefiranofaciens Fujisawa et al. 1988. Int J Syst Evol Microbiol 54, 551-556.

Wayne, L. G., Brenner, D. J., Colwell, R. R., Grimont, P. A. D., Kandler, O., Krichevsky, M. I., Moore, L. H., Moore, W. E. C., Murray, R. G. E. \& other authors (1987). International Committee on Systematic Bacteriology. Report of the ad hoc committee on reconciliation of approaches to bacterial systematics. Int J Syst Bacteriol 37, 463-464. 